\title{
Alta Schutte
}

\section{ISH President 2018-2020}

Dear Members,

With the Holiday Season around the corner, I cannot believe how quickly this year has run out! This is probably due to every month being packed with exciting activities and meetings!

One particular highlight worth sharing is that on 1 July 2019, the World Health Organization added fixed dose combination therapy to the WHO Essential Medicines List. This is a significant step forward as single-pill combinations (SPCs) is the emerging best practice for convenient hypertension control and improving patient adherence -

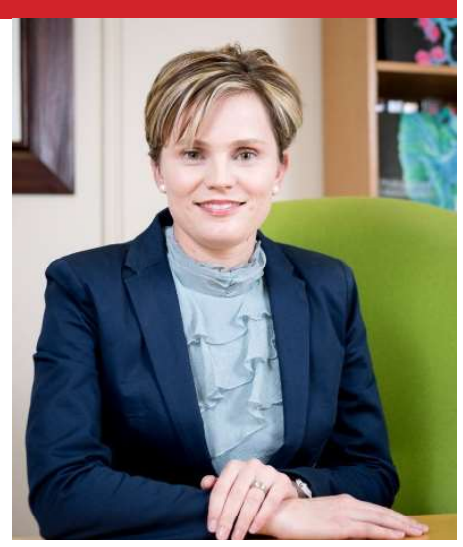
aligned with the recommendations for SPCs in multiple national and international hypertension guidelines (Table republished with permission from The Lancet). As stated in a related Correspondence to The Lancet "countries must now implement policies that put single-pill combinations in the hands of the patients who need them"."

\begin{tabular}{|c|c|c|c|c|c|c|c|}
\hline & $\begin{array}{l}\text { ACC/AHA } \\
2017\end{array}$ & $\begin{array}{l}\text { ESC/ESH } \\
2018\end{array}$ & $\begin{array}{l}\text { India } \\
2013\end{array}$ & $\begin{array}{l}\text { China } \\
2010\end{array}$ & $\begin{array}{l}\text { Thailand } \\
2015\end{array}$ & $\begin{array}{l}\text { LASH } \\
2017\end{array}$ & $\begin{array}{l}\text { WHO } \\
\text { HEARTS }\end{array}$ \\
\hline \multicolumn{8}{|c|}{ When to use two blood pressure lowering drugs } \\
\hline $\begin{array}{l}\text { Not controlled on } \\
\text { monotherapy }\end{array}$ & Yes & Yes & Yes & Yes & Yes & Yes & Yes \\
\hline $\begin{array}{l}\text { Initial treatment for all } \\
\text { individuals }\end{array}$ & No & Yes* & No & No & No & Yes & No \\
\hline $\begin{array}{l}\text { Initial treatment for selected } \\
\text { individuals, eg, those who } \\
\text { are }>20 / 10 \mathrm{~mm} \mathrm{Hg} \text { from } \\
\text { goalt or at high } \\
\text { cardiovascular risk }\end{array}$ & Yes & Yes & Yes & Yes & Yes & Yes* & Yes \\
\hline \multicolumn{8}{|c|}{ When to use single-pill combinations } \\
\hline $\begin{array}{l}\text { Recommended to substitute } \\
\text { for separate pills to improve } \\
\text { adherence }\end{array}$ & Yes & Yes & Yes & Yes & NR & Yes & NR \\
\hline $\begin{array}{l}\text { ACC=American College of Cardio } \\
\text { ESH=European Society of Hypert } \\
{ }^{*} \text { Consider monotherapy in patie } \\
\text { or patients who are frail or aged } \\
\text { blood pressure. Adapted from Sa }\end{array}$ & $\begin{array}{l}\text { ogy. } \mathrm{AHA}=\mathrm{An} \\
\text { ension. } \mathrm{LASH} \\
\text { ats with low-r } \\
80 \text { years. } † \mathrm{Sc} \\
\text { lam et al. }{ }^{4}\end{array}$ & $\begin{array}{l}\text { nerican Hea } \\
=\text { Latin Amer } \\
\text { isk grade } 1 \text { I } \\
\text { me referred }\end{array}$ & $\begin{array}{l}\text { t Associa } \\
\text { ican Soci } \\
\text { ypertens } \\
\text { to this a }\end{array}$ & $\begin{array}{l}\text { tion. ESC } \\
\text { ty of Hyp } \\
\text { on (systc } \\
\text { stage II I }\end{array}$ & $\begin{array}{l}\text { European So } \\
\text { ertension. N } \\
\text { ic blood pres } \\
\text { ypertension }\end{array}$ & $\begin{array}{l}\text { ciety of } C \\
2=\text { not rep } \\
\text { sure }<15 \\
\text { or markec }\end{array}$ & $\begin{array}{l}\text { ardiology. } \\
\text { orted. } \\
\text { d increased }\end{array}$ \\
\hline
\end{tabular}

Please also take note of the following highlights and news bits:

- On 15 September 2019 abstract submission opened for the Joint ESH-ISH Meeting to be held in Glasgow, Scotland from 29 May to 1 June 2020. Abstract submission closes by 29 November, so please save these dates carefully! Reduced registration fees are also available until 15 February - so register early here:

https://www.hypertension2020.org. 
With exciting speakers already confirmed, this event is one not to be missed. Stay updated by following the event on Twitter with \#Hypertension2020. Highlights to look forward to are:

o The release of the $\mathbf{2 0 2 0}$ ISH Global Hypertension Guidelines catering for the needs of those in low resource settings and high resource settings, chaired by Thomas Unger. Watch this space!

o Recognising new investigators, life-time achievers, women scientists and those working in the developing world with ISH awards. In the coming months the Chair of the Awards Committee, George Stergiou, will invite you all to submit nominations for the various awards (http://ish-world.com/activities/awards-prizes.htm).

o For the first time, the ISH will also recognise and honour members of the Society who have distinguished themselves through excellence in clinical practice or research in the field of hypertension, by awarding "Fellows of the International Society of Hypertension" (FISH). FISH status will be a symbol of excellence, and will represent recognition by the ISH of our members's scientific and professional accomplishments in the field of hypertension. Members will be invited during the coming months to apply online.

o Sessions by the Women in Hypertension Research Committee and New Investigator Committee including several topics such as career planning.

o With the meeting being in the month of May, there will be specific activities on May Measurement Month, including scientific sessions where investigators from around the world will have the opportunity to share their experiences.

- Please note that the official journal of the Society, the Journal of Hypertension is advertising a Call for Applications for a new Editor-in-Chief. http://ish-world.com/data/uploads/Call for Editor JH.pdf Applications should be submitted by 1 December 2019.

- The ISH Committee handling bids for the 2024 ISH meeting is chaired by Fadi Charchar. Numerous applications were received, and applicants shortlisted will have the opportunity to present their bids at the ESH-ISH Joint Meeting in Glasgow. The winning bid will also be announced there, and I am very curious to know where we will all be going in 2024.

Finally, may every member have a peaceful Holiday Season - taking some rest and enjoying time with family and friends. I am greatly looking forward to encounter all of you during ISH events in the new year.

With my very best wishes,

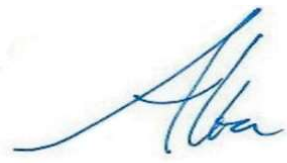

\section{Alta Schutte - alta.schutte@nwu.ac.za}

${ }^{1}$ Benjamin IJ, Kreutz R, Olsen MH, Schutte AE, Lopez-Jaramillo P, Frieden TR, Sliwa K, Lackland DT, Brainin M. Fixed-dose combination antihypertensive medications. Lancet 2019; 394: 637-638. http://dx.doi.org/10.1016/S0140-6736(19)31629-0

\section{THE SECRETARY'S VOICE}

\section{DOI: $10.30824 / 1911-4$}

\section{Thomas Unger}

ISH Secretary

CARIM - School for Cardiovascular Research,

Maastricht University, Maastricht, The Netherlands

One of the major current tasks of our Society is the elaboration of a new ISH 2020 Global Hypertension Guidelines document.

In the recent past, several local Hypertension Societies have published their own Hypertension Guidelines, among others, the US-American AHA/ACC Guidelines or the Latin American Guidelines in 2017, followed by the European ESC/ESH Guidelines in 2018, the Japanese Hypertension Guidelines and the UK-NICE Guidelines in 2019.

All these documents have their own merits. They are based on extensive review of the current literature trying to extract as much scientific evidence as possible on which to base their preventive, diagnostic and therapeutic recommendations. They are usually written by a large panel of renowned experts and have undergone several stages of external review. Some of them like the European- and the US-American Guidelines are also quite voluminous 